\title{
Gambaran Pemeriksaan Fungsi Hati pada Pasien Sirosis Hepatis yang Dirawat di Rumah Sakit Umum Daerah Arifin Achmad Provinsi Riau Periode 2013 - 2015
}

\author{
Shabrina Maharani ${ }^{1 *}$, Dasril Efendi² ${ }^{2}$ Lucyana Ani Tampubolon ${ }^{3}$
}

\begin{abstract}
Diagnosis of hepatic cirrhosis enforcement requires the anamnesis, physical examination, and examination of supporting. The purpose of this research is to know the description of examination of liver function. The results showed on the basis of age age category is the most 25-65 of the year a number of 188 men (89.1\%), most of which is gender male category a number of 135 people (63.98\%), bilirubin total showed an increase of more than $1.1 \mathrm{mg} / \mathrm{dL}$ number of 154 people (90.59\%), albumin showed a decrease of less than $3.8 \mathrm{~g} / \mathrm{dL}$ number of 181 people (92.34\%), AST shows an increase of more than $45 \mathrm{u} / \mathrm{L}$ number of 162 people (77.14\%) ALT, shows an increase of more than $35 \mathrm{u} / \mathrm{L}$ number of 146 people (69.52\%), HbsAg is present on a number of 58 patients, and 1 patient is present on the HVC.
\end{abstract}

Keyword : Hepatic Cirrhosis, Examination Of Liver Function.

Sirosis hepatis adalah suatu tahap akhir proses difus fibrosis hati progresif yang ditandai dengan adanya distorsi arsitektur lobular hati, pembentukan nodul regeneratif dan pembentukan hubungan vaskular intrahepatik antara pembuluh darah hati aferen (vena porta dan arteri hepatika) dan eferen vena hepatika. Nekrosis hepatoseluler pada sirosis hepatis mengakibatkan jaringan retikulin kolaps disertai distorsi jaringan vaskuler, deposit jaringan ikat dan regenerasi nodularis parenkim hati. Sirosis hati dapat dibedakan menjadi sirosis kompensata dan sirosis dekompensata yang hanya dapat dibedakan oleh biopsi hati. ${ }^{1}$

Sirosis hepatis merupakan salah satu dari penyebab kematian ketiga terbanyak penderita yang berusia berkisar 45-46 tahun setelah penyakit kardiovaskular dan kanker. Sirosis hepatis menduduki peringkat ketujuh penyebab kematian di dunia. Penderita sirosis hepatis lebih banyak pada laki-laki dibanding wanita dengan rasio $1,6: 1$. Umur rata-

\footnotetext{
* Penulis untuk korespondensi : maharanishabrina23 @gmail.com

1 Fakultas Kedokteran Universitas Riau

2 KJF/KSM Ilmu Penyakit Dalam Fakultas Kedokteran Universitas Riau/ RSUD Arifin Achmad Provinsi Riau.

3 KJF/KSM Patologi Klinik Fakultas Kedokteran Universitas Riau/ RSUD Arifin Achmad Provinsi Riau.
}

rata penderita sirosis hepatis terbanyak pada umur 30-59 tahun dengan puncak pada umur 40-49 tahun. Insiden sirosis hepatis di Amerika diperkirakan 0,27 \% yaitu 633.423 orang. Penyebab utama sirosis hepatis adalah hepatitis B (HBV) atau hepatitis C (HCV) di Asia Tenggara. Angka kejadian sirosis hepatis di Indonesia akibat hepatitis B berkisar antara 21,2-46,9\% dan hepatitis C berkisar 38,7-73,9\%. ${ }^{1,2}$

Penyakit hepatitis B, C dan D dapat menjadi kronis dan menimbulkan sirosis bahkan kanker hati. Virus hepatitis B telah menginfeksi sebanyak 2 milyar orang didunia, sebanyak 240 juta orang berkembang menjadi hepatitis B kronik dan 170 juta orang mengidap penyakit hepatitis $C$ yang akan mengakibatkan komplikasi berupa sirosis hepatis. ${ }^{3}$

Pemeriksaan laboratorium tes fungsi hati yaitu meliputi aminotransferase, bilirubin dan albumin. Nilai aspartat aminotransferase (AST) atau serum glutamil oksaloasetat transaminase (SGOT) dan alanin aminotransferase (ALT) atau serum glutamil piruvat transaminase (SGPT) dapat menunjukan peningkatan. AST biasanya lebih meningkat dibandingkan dengan ALT, namun bila nilai transaminase normal tetap tidak menyingkirkan kecurigaan adanya sirosis. 
Berdasarkan pemeriksaan fungsi hati yang diperiksa pada penderita sirosis hepatis, maka peneliti akan melakukan penelitian mengenai gambaran pemeriksaan fungsi hati pada pasien sirosis hepatis di Bagian Penyakit Dalam RSUD Arifin Achmad Provinsi Riau yaitu bilirubin total, albumin, AST, ALT, HbsAg dan VHC.

Rumah Sakit Umum Daerah Arifin Achmad merupakan Rumah Sakit Tipe B Pendidikan yang menjadi pusat rujukan Rumah Sakit Kabupaten/Kota se-Provinsi Riau serta tempat pendidikan mahasiwa Fakultas Kedokteran Universitas Riau dan Institusi Pendidikan Kesehatan lainnya. ${ }^{5}$ Maka peneliti ingin melakukan penelitian mengenai gambaran pemeriksaan fungsi hati pada pasien sirosis hepatis di Bagian Penyakit Dalam RSUD Arifin Achmad Provinsi Riau periode 1 Januari 2013 sampai dengan 31 Desember 2015.

\section{METODE}

Jenis penelitian ini adalah penelitian kuantitatif dengan deskriptif retrospektif, yaitu melihat data rekam medik pasien sirosis hepatis yang bertujuan untuk mengetahui gambaran fungsi hati pada pasien sirosis hepatis di Bagian Penyakit Dalam RSUD Arifin Achmad Provinsi Riau periode 1 Januari 2013 sampai dengan 31 Desember 2015.

Penelitian akan dilakukan pada bulan Desember 2016 sampai dengan bulan Maret 2017 mengambil data dari catatan rekam medik pasien sirosis hepatis di Bagian Penyakit Dalam RSUD Arifin Achmad Provinsi Riau periode 1 Januari 2013 sampai dengan 31 Desember 2015. Populasi penelitian adalah seluruh data sekunder pasien sirosis hepatis yang di rawat di Bagian Penyakit Dalam RSUD Arifin Achmad Provinsi Riau periode 1 Januari 2013 sampai dengan 31 Desember 2015 sebanyak 397 kasus. Teknik pengambilan sampel menggunakan total sampling yaitu dengan mengambil seluruh data sekunder pasien sirosis hepatis yang telah didiagnosa oleh dokter spesialis penyakit dalam RSUD Arifin Achmad Provinsi Riau pada tahun 2013-2015. Berdasarkan hasil pre riset bulan Juli 2016 pasien sirosis hepatis periode 2013-2015 sebanyak 397 kasus. Penelitian ini telah lolos kaji etik dari Unit Etika Penelitian Kedokteran dan Kesehatan Fakultas Kedokteran Universitas Riau dengan nomor No.264/ UN.19.5.1.1.8/UEPKK/2017.

\section{HASIL}

Tabel 1. Distribusi gambaran sosiodemografis berdasarkan umur dan jenis kelamin pasien sirosis hepatis yang dirawat inap di RSUD Arifin Achmad Provinsi Riau periode 2013-2015

\begin{tabular}{lcc}
\hline \multicolumn{1}{c}{$\begin{array}{c}\text { Karakteristik } \\
\text { sosio demografi }\end{array}$} & \multicolumn{2}{c}{ Jumlah } \\
\cline { 2 - 3 } & Frekuensi $(\mathrm{n}=211)$ & Persen $(\%)$ \\
\hline Umur & 3 & 1,42 \\
$15-24$ & 188 & 89,1 \\
$25-65$ & 20 & 9,48 \\
$>65$ & & \\
Jenis Kelamin & 135 & 63,98 \\
Laki-Laki & 76 & 36,02 \\
Perempuan & & \\
\hline
\end{tabular}

Berdasarkan hasil penelitian diketahui bahwa kelompok umur terbanyak pasien sirosis hepatis adalah umur 25-65 tahun sebanyak 190 orang
(90,05\%). Jenis kelamin pasien sirosis hepatis terbanyak adalah laki-laki sebanyak 135 orang (63,98\%) (tabel 1.) 
Tabel 2. Distribusi nilai bilirubin total pada pasien sirosis hepatis yang dirawat inap di RSUD Arifin Achmad periode 2013-2015 $n=170$

\begin{tabular}{ccc}
\hline Bilirubin Total $(\mathrm{mg} / \mathrm{dL})$ & Frekuensi & Persentase $(\%)$ \\
\hline $0,2-1,1$ & 16 & 9,41 \\
$>1,1$ & 154 & 90,59 \\
\hline
\end{tabular}

Berdasarkan hasil penelitian diketahui nilai bilirubin total dengan rentang nilai $0,2-1,1 \mathrm{mg} / \mathrm{dL}$ berjumlah 16 orang dengan persentase $9,41 \%$, sedangkan pasien yang memiliki nilai bilirubin total lebih dari $1,1 \mathrm{mg} / \mathrm{dL}$ adalah 154 orang dengan persentase 90,59\% dari 170 orang yang diketahui nilai bilirubin totalnya (tabel 2).

Tabel 3. Distribusi nilai albumin pada pasien sirosis hepatis yang dirawat inap di RSUD Arifin Achmad periode 2013-2015 ( $\mathrm{n}=196)$

\begin{tabular}{ccc}
\hline Albumin $(\mathrm{g} / \mathrm{dL})$ & Frekuensi & Persentase $(\%)$ \\
\hline$<3,8$ & 181 & 92,34 \\
$-3,86,0$ & 15 & 7,65 \\
\hline
\end{tabular}

Berdasarkan hasil penelitian didapatkan nilai albumin dengan nilai $>3,8 \mathrm{~g} / \mathrm{dL}$ berjumlah 181 orang dengan persentase $92,34 \%$, sedangkan pasien yang memiliki nilai albumin dengan rentang nilai 3,8-6,0 g/dL adalah 15 orang dengan persentase 7,65 \% dari 196 orang yang diketahui nilai albuminnya (tabel $3)$.

Tabel 4. Distribusi nilai AST pada pasien sirosis hepatis yang dirawat inap di RSUD Arifin Achmad periode 2013-2015 (n=210)

\begin{tabular}{ccc}
\hline AST $(\mathrm{u} / \mathrm{L})$ & Frekuensi & Persentase \\
\hline $12-35$ & 48 & 22,86 \\
$>45$ & 162 & 77,14 \\
\hline
\end{tabular}

Berdasarkan hasil penelitian didapatkan nilai AST dengan rentang nilai 3-45 $\mathrm{u} / \mathrm{L}$ berjumlah 48 orang dengan persentase $22,86 \%$, sedangkan pasien yang memiliki nilai AST dengan nilai $>45 \mathrm{u} / \mathrm{L}$ adalah 162 orang dengan persentase $77,14 \%$ dari 210 orang yang diketahui nilai albuminnya (tabel 4).

Tabel 5. Distribusi nilai ALT pada pasien sirosis hepatis yang dirawat inap di RSUD Arifin Achmad periode 2013-2015 (n=210)

\begin{tabular}{ccc}
\hline ALT $(\mathrm{u} / \mathrm{L})$ & Frekuensi & Persentase \\
\hline $5-35 \mathrm{u} / \mathrm{L}$ & 64 & $30,48 \%$ \\
$>35 \mathrm{u} / \mathrm{L}$ & 146 & $69,52 \%$ \\
\hline
\end{tabular}

Berdasarkan hasil penelitian didapatkan nilai ALT dengan rentang nilai $0-35 \mathrm{u} / \mathrm{L}$ berjumlah 64 orang dengan persentase $30,48 \%$, sedangkan pasien yang memiliki nilai ALT dengan nilai >35 u/L adalah 146 orang dengan persentase 69,52 \% dari 210 orang yang diketahui nilai albuminnya (tabel 5) 


\section{PEMBAHASAN}

\section{Karakteristik Sampel}

Hasil penelitian menunjukkan kelompok umur terbanyak pasien sirosis hepatis yang dirawat inap di bagian penyakit dalam yaitu kelompok umur 2565 tahun yaitu 190 orang $(90,05 \%)$ dan yang paling sedikit adalah kelompok umur 15-24 tahun sebanyak 3 orang (1,42\%). Hal ini sesuai dengan penelitian yang juga dilakukan di Pontianak bahwa penyakit sirosis hepatis lebih sering dialami oleh kelompok usia umur 50-59 tahun diikuti kelompok usia > 60 tahun. Berdasarkan penelitian di Pontianak tersebut dinyatakan bahwa penderita sirosis hepatis semakin meningkat seiring dengan bertambahnya usia yang diakibatkan menurunnya kapasitas fungsional baik pada tingkat seluler maupun organ. ${ }^{6}$

Jenis kelamin yang terbanyak adalah laki-laki 135 orang $(63,98 \%)$ orang dan perempuan 76 orang (36,02\%) . Hal ini sesuai dengan penelitian di RSUD DR.SOEDARSO Pontianak periode 2008-2012 bahwa pasien sirosis hati terbanyak pada laki-laki sebanyak 45 orang $(71,4 \%)$ dan perempuan 17 orang (27,4\%). Penelitian di Jogjakarta diketahui 73 pasien yang menjadi sampel dalam penelitian, 54 orang (74\%) adalah laki-laki. Hal ini terjadi kemungkinan diakibatkan karena laki-laki bekerja lebih keras tanpa memerhatikan kemampuan fisik dan mental dibandingkan perempuan. ${ }^{8}$

\section{Nilai Bilirubin Total}

Hasil penelitian didapatkan nilai bilirubin total dengan rentang nilai $0,2-1,1 \mathrm{mg} / \mathrm{dL}$ berjumlah 16 orang dengan persentase 9,41\%, sedangkan pasien yang memiliki nilai bilirubin total lebih dari 1,1 mg/dL adalah 154 orang dengan persentase 90,59 \% dari 170 orang yang diketahui nilai bilirubin totalnya.

Hasil penelitian yang dilakukan di Manado dari 30 pasien sirosis hepatis yang dijadikan sebagai subyek penelitian, rata-rata nilai bilirubin total yaitu $0,51 \mathrm{mg} / \mathrm{dL}$, nilai terendah yaitu $0,2 \mathrm{mg} / \mathrm{dL}$ dan nilai bilirubin tertinggi yatu $33 \mathrm{mg} / \mathrm{dL} .{ }^{9}$ Berdasarkan hasil penelitian yang dilakukan bahwa pada sirosis hepatis akan dijumpai peningkatan produksi bilirubin yang disebabkan oleh kegagalan fungsi ginjal, sepsis dan proses hemolisis. ${ }^{10}$

\section{Nilai Albumin}

Hasil penelitian ini menunjukkan nilai albumin $<3,8 \mathrm{~g} / \mathrm{dL}$ berjumlah 181 orang dengan persentase $92,34 \%$, sedangkan pasien yang memiliki nilai albumin dengan rentang nilai 3,8 -6,0 g/dL adalah 15 orang dengan persentase 7,65\%. Berdasarkan penelitian yang dilakukan di Manado bahwa rata rata nilai albumin pasien sirosis hati didapatkan 2,741 gr/ dL dengan nilai albumin terendah yaitu $1,7 \mathrm{gr} / \mathrm{dL}$ dan nilai albumin yang tertinggi 4,4 gr/dL. Sintesis dan katabolisme albumin terjadi di hati. Sirosis hati menunjukkan nilai produksi albumin yang rendah. Perubahan nilai albumin dapat menunjukkan peningkatan permeabilitas vaskuler karena sepsis dan asites. ${ }^{10}$ Kadar nilai albumin bergantung pada beberapa hal, yaitu proses produksi, sekresi sel hati, penyebaran cairan dalam tubuh dan degradasinya. ${ }^{11}$

\section{Nilai AST}

Hasil penelitian mendapatkan nilai AST dengan rentang nilai $12-45 \mathrm{u} / \mathrm{L}$ berjumlah 48 orang dengan persentase $22,86 \%$, sedangkan pasien yang memiliki nilai AST dengan nilai $>45 \mathrm{u} / \mathrm{L}$ adalah 162 orang dengan persentase 77,1 \% dari 210 orang yang diketahui nilai albuminnya. Peningkatan aktivitas enzim ini dalam serum kemungkinan berasal dari kebocoran dari sel yang rusak atau cedera pada hepatosit. Enzim-enzim ini meningkat dalam berbagai bentuk penyakit hati dan terutama penyakit-penyakit yang terkait dengan nekrosis hepatosit yang signifikan seperti hepatitis virus akut yang merupakan penyebab paling umum peningkatan AST. ${ }^{12}$ Penelitian di India menunjukkan adanya peningkatan yang signifikan enzim - enzim hati pasien seperti bilirubin dan SGOT. ${ }^{13}$

\section{Nilai ALT}

Hasil penelitian mendapatkan nilai ALT dengan rentang nilai 5-35 $\mathrm{u} / \mathrm{L}$ berjumlah 64 orang dengan persentase $30,48 \%$, sedangkan pasien yang memiliki nilai ALT dengan nilai $>35 \mathrm{u} / \mathrm{L}$ adalah 146 orang dengan persentase 69,52 \% dari 210 orang yang diketahui nilai albuminnya. Penelitian yang dilakukan di India menunjukkan bahwa nilai AST dan ALT dapat meningkat hingga 6 kali dari nilai normal. ${ }^{27}$ Peningkatan SGOT dan SGPT juga dapat 
diakibatkan oleh traktus biliaris obstruktif akut atau obstruktif kronik yang dapat merusak parenkim hati. ${ }^{14}$

\section{HbsAg dan HVC}

Hasil penelitian menunjukkan sebanyak 58 dari 129 pasien yang telah diperiksa HbsAg, teridentifikasi HbsAg kualitatif reaktif. Penelitian yang dilakukan di Iran, dari 27 pasien yang didiagnosis sirosis hepatis, diketahui 40,74 \% pasien memiliki HbsAg yang reaktif. ${ }^{15}$

Hasil penelitian menunjukkan bahwa jumlah pasien sirosis hepatis yang memiliki HVC reaktif adalah satu orang. Reaksi inflamasi yang dilibatkan melalui sitokin-sitokin pro-inflamasi seperti TNFalpha, menyebabkan rekruitmen sel-sel inflamasi dan menyebabkan aktivasi sel-sel stelata di hati. Sel-sel kemudian berproliferasi dan teraktivasi menjadi sel - sel miofibroblas. Reaksi inflamasi yang terjadi tidak berhenti sehingga fibrosis semakin lama semakin banyak dan sel sel hati yang ada semakin sedikit. Proses ini dapat menimbulkan kerusakan sel hati yang lanjut dan menjadi sirosis. ${ }^{16}$

\section{KESIMPULAN}

Umur yang terbanyak adalah pada usia dewasa muda hingga lanjut usia dan lebih sering terjadi pada laki-laki. Pada pemeriksaan hati ditemukan peningkatan bilirubin total, penurunan albumin, peningkatan AST dan ALT serta hampir setengah dari pasien sirosis hepatis mempunyai riwayat hepatitis B kronik.

\section{DAFTAR PUSTAKA}

1. Nurdjanah S. Sirosis hepatis. Dalam: Sudoyo AW, Setiyohadi B, Alvi I, Simadibrata MK, Setiati S, editor. Buku Ajar Ilmu Penyakit Dalam. Edisi ke6. Jakarta: Departemen Ilmu Penyakit Dalam Fakultas Kedokteran Indonesia; 2014. hal 197883.

2. Yunellia Z. Patasik BJ. Waleleng F W. Profil pasien sirosis hepatis yang dirawat inap di RSUD Prof.Dr.R.D. Kandou Manado Periode Agustus 2012-Agustus 2014. [Skripsi]. Fakultas Kedokteran Universitas Sam Ratulangi Manado
Bagian Ilmu Penyakit Dalam Fakultas Kedokteran Universitas Sam Ratulangi. 2014.

3. Kementrian Kesehatan Republik Indonesia. Pusat data informasi kesehatan Republik Indonesia. Situasi dan analisis hepatis. Jakarta. 2014

4. Aiden P. Hepatic Chirrhosis. In : Jenny E. Heathcote, editor. Sherlock's Disease of the liver and billiary system. Ireland; 2007. P 103-18.

5. Profil RSUD Arifin Achmad Provinsi Riau. [cited :2011]

6. Phillip S. Treatment of patients with cirrhosis. Division of Digestive Disease, University of California, Los Angeles. 2016. p :767.

7. Seagloione S. The Epidemiology of cirrhosis in the United States : A population based study. Department of internal medicine, Division of Hepatology, Loyola University Medical Center. 2015.

8. Hasan I, Anggareni I. Peran albumin dalam pelakasanaan sirosis hati. Divisi Hepatologi, Departemen Ilmu Penyakit Dalam FKUI/RSCM . Jakarta. Juni 2008.1(2): 3.

9. Tio, Simamora CA. Hubungan komplikasi, skor child-turcotte, dan usia lanjut sebagai faktor risiko kematian pada sirosis hati di RSUD DR.Soedarso Pontianak tahun 2008-2012. Fakultas Kedokteran Universitas Tanjung Pura. Pontianak. 2013.

10. Saksana R A. Correlation between the severity of liver chirrosis ( child pugh score ) \& Qtc interval prolongation. Department of Internal Medicine, University of Gadjah Mada. Jogjakarta. 2012. hal : 158.

11. Poluan MP. Hubungan derajat keparahan sirosis hati dan nilai laju glomerulus pada sirosis hati. [Skripsi]. Fakultas Kedoktean Universitas Sam Ratulangi. Manado. 2015.

12. Soo J.B. Acute Exacerbation in hepatitis of liver cirrhosis with very high levels of alphaphetoprotein but no occurence of hepatocelluler carcinoma. Department of Gastroenterology, Boondang Jaeseng General Hospital, Sungnam, Korea. Maret 2005. Korea; 20(1): 80-5. 
13. Rudrajit P. Study of serum uric acid in chronic liver disease and relation with other parameter. Department Of Medicine, Medical College. Kolkata, West Bengal, India. July, 2013. p : 164.

14. Mahaboob S. Serum enzyme levels in various liver disease. International Journal of Medical Research and Health Science. Fathima Instituted of Medical Sciences. Andrapradesh, India. May, 2013. p : 397.
15.Juatmadja BA. The correlation of transaminase and liver disease. Department Of Clinical Pathology Faculty of Medicine Udayana University. 2015. p : 7.

16. Ansari N. Hepatitis B virus genotyping among patients with cirrhosis. Department of Virology, Tehran University of Medical Science, Iran. 2014. p:4. 